\title{
Effects of migraine disease on the vestibulocochlear system
}

\section{Migren hastalığının vestibulokoklear sistem üzerine etkileri}

\author{
Murat Zaim, Baran Acar, Emrah Çelik
}

\begin{abstract}
Objective: Migraine patients have tendency to have vestibular and auditory system problems. The aim of this study is to evaluate vestibule cochlear system of patients with migraine with Transient-evoked otoacoustic emissions (TEOAE) video-nystagmography (VNG) and caloric test.
\end{abstract}

Methods: 39 patients diagnosed with migraine and control group of 21 healthy volunteers were included in this study. Before they were included in the study, all of them were examined and those who has acute otitis media, chronic otitis media, tympanic membrane perforation, external otitis, ear surgery history and head trauma were excluded from the study. All patients and volunteers were tested by TEOAE, VNG and caloric tests. In evaluating the statistical data, SPSS 15.0 was utilized.

Results: When TEOAE values for the migraine group and for the control group are compared, it is found statistically significant that the TEOAE values for the migraine group is lower than those for the control group. This result shows that there can be a pathology that is able to affect cochlear functions in migraine disease. As for VNG test results, a statistically significant difference cannot be determined between migraine and control groups. Moreover, the identification of canal paresis in caloric test indicates that peripheral vestibular problems accompany migraine disease.

Conclusion: Evaluating vestibulocochlear system of migraine patients with TEOAE, VNG and caloric tests has been an important task for identifying vestibular imperfections accompanying these patients and for predicting potential auricular pathologies. J Clin Exp Invest 2015; 6 (1): 1-4

Key words: Migraine, TEOAE, video-nystagmography

\section{ÖZET}

Amaç: Migren hastalarında vestibüler problemler ve işitsel problemler görülebilmektedir. Bu çalışmanın amacı migren hastalarının koklea-vestibüler sistemini Transient evoked otoacustic emmission (TEOAE) video-nistagmografi ( VNG) ve kalorik test ile değerlendirmektir.

Yöntemler: Bu çalışmaya migren tanısı konmuş 39 hasta ile kontrol grubu olarak 21 sağlıklı gönüllü dahil edilmiştir. Hasta ve sağlıklı gönüllüler çalışmaya alınmadan önce tam bir muayeneden geçirilmiş ve akut otit, kronik otit, timpan zar perforasyonu, dış kulak yolu iltihabı olanlar, kulak cerrahisi geçirenler ve kafa travması geçirenler çalışma dışı bırakılmıştır. Çalışmaya katılanların hepsine TEOAE VNG ve kalorik test uygulanmıştır. İstatistiki verilerin değerlendirilmesinde SPSS 15.0 programı kullanılmıştır.

Bulgular: Migren ve control grubu karşılaştırıldığında, migren grubu TEOAE değerlerinin kontrol grubuna gore istatiksel olarak anlamlı derecede düşük olduğu görülmüştür. Bu durum, migren hastalığında koklear fonksiyonları etkileyebilecek bir patolojinin olabileceğini bize göstermektedir.

VNG test sonuçları değerlendirildiğinde ise; migren grubu ile kontrol grubu arasında istatiksel olarak anlamlı bir fark saptanamamıştır. Kalorik testte kanal parezisi saptanması, migren hastalarında eşlik eden periferik vestibüler problemler olabileceğine işaret etmektedir.

Sonuç: Migren hastalarında vestibülokoklear sistemi; TEAOE, VNG ve kalorik testler ile değerlendirmek, bu hastalarda eşlik edebilecek vestibüler bozukları saptamak ve oluşabilecek işitsel patolojiler öngörebilmek için önem arz etmektedir.

Anahtar kelimeler: Migren, TEOAE, video-nistagmografi 


\section{INTRODUCTION}

Migraineis a type of headache that usually occurs in attacks. It affects $14 \%$ of the whole population and nearly $18 \%$ of the women population [1].

The pathophysiology of migraine-related auditory-vestibular symptoms has not been fully clarified but its clinical manifestation is varied [2]. Various types of balance disorders have been reported during headache crises in migraine patients, such as rotational vertigo, positional vertigo, dizziness, intolerance to head movement and other less common findings [3].

Reported auditory disorders which may be related to headache-induced stress include phonophobia (intolerance to loud noise) and hyperacusis (abnormal noise sensitivity), first described by Tissot in 1778 (cited by Sachs et al., 1970) [4].

Migraine attacks may persist for 4 hours to 72 hours. Patients feel completely normal during the attacks themselves. Migraine pain is usually mild to moderate or severe and interferes with a person's daily activities. In addition to hearing loss; tinnitus, vertigo and dizziness may be associated with headache in these patients. It is important to reveal the cause of the symptoms that may occur with migraine and quantitative tests must be evaluated in order to determine the relationship.

The aim of this study is to evaluate the vestibulocochlear system of migraine patients with videonystagmography (VNG), caloric test and transient evoked otoacoustic emission test (TEOAE).

\section{METHODS}

This study was performed at Ankara Keçiören Training and Research Hospital Otolaryngology and Neurology clinics in the period between February and June 2012. For this study, local ethics committee approval was taken from Ankara Keçiören Training and Research Hospital Ethics Committee.

This study was conducted in Keçiören Training and Research Hospital Neurology policlinic with 39 patients with diagnosis of migraine without aura according to International Headache Society (IHS) diagnostic criteria. They were compared with a control group of 21 healthy volunteers selected among the department employees. Patients with previous diagnosis of neuro-otological disease (labyrinthine diseases, benign paroxysmal positional vertigo, etc.), cardiovascular diseases, pulmonary disorders, metabolic alterations tympanic membrane perforation, otitis externa, otitis media, ear surgery history, or cranial trauma were excluded from the study.

All of the patients in the migraine and the control group were examined according to tests below:1) A detailed head and neck examination; 2) fiberoptic nasal, pharyngeal and laryngeal examination; 3) neurological examination 4) evaluation of eye movement disorders using oculomotility tests recorded by videonystagmography (VNG) 5) caloric vestibular responses with cold and warm water stimulation and recorded by VNG.

The oculomotility test evaluation included: a) voluntary saccadic eye movements: latency, maximal velocity, accuracy; b) smooth-pursuit movements: latency, gain, morphology; c) optokinetic nystagmus: slow-phase angular velocity, gain, symmetry; d) nystagmus during caloric vestibular tests: duration, frequency, slow-phase angular velocity with the classic Jongkees' formula [5].

6) Transient-evoked otoacoustic emissions; TEOAEs records were taken from each ear of all subjects by the help of an Otodynamics ILO V6 analyzer. A standard nonlinear click stimulus of $80-\mu \mathrm{sec}$ duration was identified at a repetition rate of $50 \mathrm{~Hz}$ and a sound level of $80( \pm 3)$ peak equivalent $\mathrm{dB} S \mathrm{SPL}$. The response was averaged over 260 acquisitions and the total (mean) nonlinear TEOAE response amplitude (dB SPL) was analyzed. The level of random noise was controlled by setting the automatic noise rejection at $47.3 \mathrm{~dB}$ in all tested subjects. The detailed analysis of the parameters was carried out using SPSS 15.0 statistics software manufactured by SPSS Inc. Frequencies, mean values, standard deviations, medians, minimum and maximum values within the treatment groups were given for the various variable forms. All data were synchronized and subsequently analyzed in SPSS. A significance level of $p<0.05$ was defined for all statistical tests.

\section{RESULTS}

The migraine group included 36 females and 3 males. Mean age of all patients was 34.8 years (range19-62 years). Mean age of the Control group was 28.6 years (range 21-42 years) and the female/ male ratio was $2: 1$. Results regarding related tests have been summarized as follows:

\section{Transient evoked otoacoustic emissions}

There was significant difference with respect to TEOAE means left ear $1000 \mathrm{~Hz}$, right ear 1400 , 
2000, 2800, $4000 \mathrm{~Hz}$ ) between the migraine and control groups $(p<0,05)$ (Figure1)

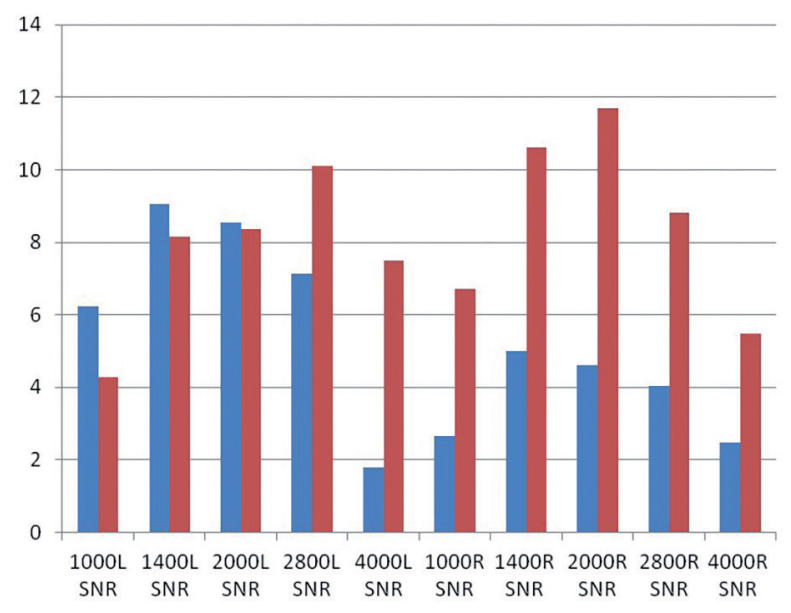

Figure 1. Transient evoked otoacoustic emission test values; blue color migraine group, red color control group

\section{Videonystagmography}

There was no significant difference between migraine and control groups in terms of VNG test results. $(p>0.05)$

\section{Caloric vestibular Test}

After the caloric test was completed, canal paresis and values were calculated according to the Jonkees formula. The canal paresis value over $20 \%$ level was considered as positive. Directional preponderance value over $30 \%$ level was considered as positive.

Caloric vestibular tests for migraine group demonstrated abnormal findings for 12 patients and normal vestibular functions for the remaining $17 \mathrm{pa}-$ tients. Canal paresis was determined for 12 patients in migraine group. Furthermore directional preponderance was determined 3 of these 12 patients. The control group presented normal vestibular tests in all cases. Thus, there was significant difference between migraine and control groups in terms of caloric vestibular test results. $(p>0.05)$

\section{DISCUSSION}

Migraine is a chronic, paroxysmal, and neurovascular disease. It usually starts around the age of thirty [6]. It is in the group of primary headaches at International Headache Societies (IHS) classification. The pathophysiology of migraine-related auditoryvestibular symptoms has not been fully clarified, but its clinical manifestation is varied [2]. Most of the vestibulocochlear symptoms are motion sickness dizziness and phonofobia. In our study, we appraised vestibulocochlear functions of migraine patients with VNG, caloric vestibular test and transient otoacoustic emission test.

Cochleavestibular blood flow may change as a result of trigeminal activation in migraine patients. This situation may lead to changes in the outer hair cells. Due to this fact, change can be evaluated by otoacoustic emission test. Bolay et al. applied otoacoustic emission to migraine patients. In Bolay's study, he did not find a statistically significant difference between TEOAE values taken from different groups. On the other hand, distortion product OAE values were appeared to be lower in patients with migraine [7]. Hamedet al. in their study evaluated cochlea and peripheral auditory system with TEOAE and distortion product otoacoustic emissions (DPOAE). In this study, 58 migraine patients and 40 healthy volunteers were included. As for migraine patients were detected reduced in TEOAE response especially 1-3-4 khz. Therefore, it was determined that migraine patients have subclinical changes regarding cochlear function [8]. Murdin L. et all. in their study elaborated on vestibular migraine patients with otoacoustic emissions. In the study 33 vestibular migraine patients and 31 nonmigraine volunteer were included. As a result, they found that otoacoustic emissions response reduced in vestibular migraine disease group but this wasn't correlated with phonophobia or disease duration [9]. In our study, TEOAE values appeared to be lower in patients with migraine. The reason for the different results of these studies may be associated with patients' age and time of diagnosis of migraine.

On the other hand, Toglia et al. applied electronystagmography to migraine patients. It was determined that $80 \%$ of the patients were found to be abnormal in terms of caloric test. Moreover, 7 patients had canal paresis and 9 patients had directional preponderance [10]. Similarly, Cass et al. included 100 patients with migraine and vertigo in their study where $22 \%$ of the patients were found to be abnormal in terms of caloric test [11]. Vitkovic et al. incorporated 523 patients with migraine and vestibular symptoms in their study. They found that absolute migraine patients had periferal vestibular hipofunction [12].

Rzeski et al. applied electronystagmography and videonystagmography to migraine patients. In their study, it had been established that $54 \%$ of migraine patients show vestibular dysfunction. This 
condition is thought to be associated with the migraine duration and migraine frequency [13].

Cutrer et al. applied electronystagmography to 91 migraine patients. $20 \%$ of the patients were observed to have canal paresis in terms of the caloric test results [14]. Dash et al. performed a similar study. Again, $26 \%$ of the patients were observed to have canal paresis in terms of the caloric test results [15].

Compared to others summarized above; the result of our study was similar to other studies In our study $30 \%$ of the migraine patients appeared to have canal paresis. These findings indicate that migraine patients have tendency to have peripheral vestibular dysfunction. The caloric test may assist establishing this peripheral vestibular dysfunction.

In conclusion, lower TEOAE values and canal paresis were determined for patients with migraine. These findings show that migraine disease may lead to cochlear patologoies and periferal vestibular dysfunction and this may help to better identify some of the vertiginous and cochlear symptoms for migraine patients.

\section{REFERENCES}

1. Stovner LJ, Hagen K, Jensen R, et al. The global burden of headache: a documentation of headache prevalence and disability worldwide. Cephalalgia 2007;27:193-210.

2. Furman JM, Sparto PJ, Soso M, et al. Vestibular function in migraine-related dizziness: a pilot study. J Vestib Res 2005;15:327-332.

3. Shepard NT. Differentiation of Ménière's disease and migraine-associated dizziness: a review. J Am Acad Audiol 2006;17:69-80.
4. Sachs OW. Migraine: the evolution of a common disorder. $1^{\text {st }}$ ed. London: Faber \& Faber; 1970.

5. Jongkees LB. Thermic test and electronystagmography. Acta Otorhinolaryngol Belg 1965;19:455-464.

6. Stewart WF, Schecter A, Rasmussen BK. Migraine prevalence: A review of population based studies. Neurology 1994;44:17-23.

7. Bolay $H$, Bayazit YA, Gündüz B, et al. Subclinical dysfunction of cochlea and cochlear efferents in migraine: an otoacoustic emission study. Cephalalgia 2008;28:309-317.

8. Hamed SA, Youssef AH, Elattar AM. Assessment of cochlear and auditory pathways in patients with migraine Am J Otolaryngol 2012;33:385-394.

9. Murdin L, Premachandra P, Davies R, Sensory Dysmodulation in vestibular migraine: an otoacoustic emission suppression study. Laryngoskope 2010;120:1632-1636.

10. Toglia JU, Thomas D, Kuritzky A. Common migraine and vestibular function. Electronystagmographic study and pathogenesis. Ann Otol Rhinol Laryngol 1981;90:267-271.

11. Cass SP, Furman JM, AnkerstjerneK, et al. Migrainerelated vestibulopathy. Ann Otol Rhinol Laryngol 1997;106:182-189.

12. Vitkovic J, Paine M, Rance G. Neuro-otological findings in patients with migraine- and nonmigraine-related dizziness. Audiol Neurootol 2008;13:113-122.

13. Rzeski M, Stepień A, Kaczorowski Z. Evaluation of the function of the vestibular system in patients with migraine. NeurolNeurochir Pol 2008;42:518-524.

14. Cutrer FM, Baloh RW. Migraine-associated dizziness. Headache 1992;32:300-304.

15. Dash AK, Panda N, Khandelwal G, et al. Migraine and audiovestibular dysfunction: is there a correlation? Am J Otolaryngol 2008;29:295-299. 